\title{
Alzheimer disease macrophages shuttle amyloid-beta from neurons to vessels, contributing to amyloid angiopathy
}

\author{
Justin Zaghi • Ben Goldenson • Mohammed Inayathullah • Albert S. Lossinsky • Ava Masoumi • Hripsime Avagyan • \\ Michelle Mahanian • Michael Bernas • Martin Weinand • Mark J. Rosenthal • Araceli Espinosa-Jeffrey • \\ Jean de Vellis $\cdot$ David B. Teplow $\cdot$ Milan Fiala
}

Received: 26 September 2008 / Revised: 5 December 2008 / Accepted: 30 December 2008 / Published online: 13 January 2009

(C) The Author(s) 2009. This article is published with open access at Springerlink.com

\begin{abstract}
Neuronal accumulation of oligomeric amyloid- $\beta$ $(A \beta)$ is considered the proximal cause of neuronal demise in Alzheimer disease (AD) patients. Blood-borne macrophages might reduce $A \beta$ stress to neurons by immigration into the brain and phagocytosis of $\mathrm{A} \beta$. We tested migration and export across a blood-brain barrier model, and phagocytosis and clearance of $\mathrm{A} \beta$ by $\mathrm{AD}$ and normal subjects' macrophages. Both $\mathrm{AD}$ and normal macrophages were inhibited in $A \beta$ export across the blood-brain barrier due to adherence of $A \beta$-engorged macrophages to the endothelial layer. In comparison to normal subjects' macrophages, $\mathrm{AD}$ macrophages ingested and cleared less $A \beta$, and underwent apoptosis upon exposure to soluble, protofibrillar, or fibrillar $\mathrm{A} \beta$. Confocal microscopy of stained $\mathrm{AD}$ brain sections
\end{abstract}

J. Zaghi and B. Goldenson contributed equally.

Electronic supplementary material The online version of this article (doi:10.1007/s00401-008-0481-0) contains supplementary material, which is available to authorized users.

J. Zaghi · B. Goldenson · A. Masoumi · H. Avagyan ·

M. Mahanian · M. Fiala $(\bowtie)$

Department of Orthopaedic Surgery,

UCLA-Orthopaedic Hospital Research Center,

615 Charles E. Young Drive South, Room 410,

Los Angeles, CA 90095-7358, USA

e-mail: fiala@mednet.ucla.edu

M. Inayathullah · D. B. Teplow

Department of Neurology, David Geffen School of Medicine,

University of California, Los Angeles, CA 90095, USA

M. Inayathullah · D. B. Teplow

Molecular Biology Institute, University of California,

Los Angeles, CA 90095, USA

M. Inayathullah · D. B. Teplow

Brain Research Institute, University of California,

Los Angeles, CA 90095, USA revealed oligomeric $A \beta$ in neurons and apoptotic macrophages, which surrounded and infiltrated congophilic microvessels, and fibrillar $A \beta$ in plaques and microvessel walls. After incubation with AD brain sections, normal subjects' monocytes intruded into neurons and uploaded oligomeric $A \beta$. In conclusion, in patients with $A D$, macrophages appear to shuttle $A \beta$ from neurons to vessels where their apoptosis may release fibrillar $A \beta$, contributing to cerebral amyloid angiopathy.

Keywords Macrophages - Amyloid-beta - Apoptosis . Alzheimer $\cdot$ Congophillic $\cdot$ Angiopathy

\section{Introduction}

The amyloid hypothesis proposes that amyloid- $\beta$ (A $\beta)$ accumulation in the brain is the cause of Alzheimer disease

\author{
A. S. Lossinsky \\ New Jersey Neuroscience Institute, \\ JFK Medical Center, Edison, NJ 08818, USA \\ M. Bernas $\cdot$ M. Weinand \\ Department of Surgery, University of Arizona, \\ Tucson, AZ, USA \\ M. J. Rosenthal \\ Department of Medicine, \\ Greater LA VA Medical Center and UCLA School of Medicine, \\ Los Angeles, CA 90095, USA
}

A. Espinosa-Jeffrey · J. de Vellis

Department of Neurobiology,

David Geffen School of Medicine,

Los Angeles, CA 90095, USA 
[20]. $A \beta$ is potentially generated from $A \beta$ precursor protein (APP) wherever APP and the $\beta$ - and $\gamma$-secretases are located, such as the endoplasmic reticulum and Golgi apparatus, but most is produced at the plasma surface or in the secretory pathway [25]. A $\beta$ generation may also occur during autophagic turnover of APP-rich organelles [32]. Increasing molecular weight assemblies of $A \beta$ accumulate both extra- and intra-neuronally in Alzheimer disease (AD) brain [25]; of these assemblies, at least the intraneuronal oligomeric $A \beta$ has pathological consequences [43]. $A \beta$ is cleared physiologically across the blood-brain barrier by low-density lipoprotein receptor-related protein-1 [35]. Despite this physiological clearance, $A \beta$ is found to accumulate in neurons and extracellular deposits since the first year of life. The pathological consequences in $\mathrm{AD}$ patients are intraneuronal accumulation of oligomeric $A \beta$ in multivesicular bodies [18] and neuronal death. Surprisingly, the total neuronal load of $\mathrm{A} \beta$ is not predictive of neurofibrillary degeneration [47].

Brain amyloidosis of $\mathrm{AD}$ patients is considered to be related to insufficient clearance rather than over-expression of $A \beta$ [42]. Promising strategies for immune clearance of $A \beta$ include $A \beta$ vaccination [48], intravenous gamma-globulin [39], humanized anti-A $\beta$ antibody (Bapineuzumab ${ }^{\circledR}$ ), and transcriptional modulation of macrophages, such as by use of curcuminoids [15]. Studies of AD brain tissues [11] and, recently, of APP transgenic mice brain tissues [28, 30, 37] suggest that blood-derived macrophages and microglia, rather than resident brain microglia, have a key role in the clearance of $\mathrm{A} \beta$.

Previous studies have identified basic immune mechanisms necessary for clearance of $\mathrm{A} \beta$ by macrophages. $\mathrm{A} \beta$ induced adhesion molecules and chemokines CCL3 (MIP-1 $\alpha$ ), CCL4 (MIP-1 $\beta$ ), and CCL2 $[9,17,38]$ act on macrophages, microglia, and astrocytes, promoting monocyte migration, differentiation [9], and survival [19]. In mouse macrophages and microglia, the class B scavenger receptor type 2 (CD36) is crucial for induction by $A \beta$ of chemokines, cytokines, and reactive oxygen species [6, 34], and exposure to $A \beta$ initiates the signaling cascade that links CD36 scavenger receptor to the actin cytoskeleton and diverse processes such as cellular migration, adhesion, and phagocytosis [41]. Fucoidan inhibits both class A and B scavenger receptor interactions [21], but, in our experience, does not inhibit $A \beta$ phagocytosis by human macrophages (Fiala et al. unpublished data). Recent studies suggest a role for Toll-like receptors (TLR's) in A $\beta$ clearance: $T L R$ 's are transcriptionally downregulated in AD patients' monocytes [15], and TLR-2 signaling enhances $A \beta$ uptake by microglia [4]. Importantly, mononuclear cells of most patients differ from those of normal subjects by transcriptional downregulation of $\beta-1,4-$ mannosyl-glycoprotein $4-\beta-\mathrm{N}$-acetylglucosaminyltransferase (MGAT-3), an enzyme important in phagocytosis of $A \beta[15]$.
Immunohistochemical studies brought new insights into the immune clearance of $A \beta$ by macrophages in human brain. AD brain contains 11 times as many cyclooxygenase (COX-2)-positive macrophages as age-matched control brain [11], and a subset of these macrophages is inducible nitric oxide (NO) synthase (iNOS)-positive [10]. Monocyte immigration might be orchestrated by neuronal and microglial chemokine RANTES and cytokine interleukin-1 $\beta$ (IL1ß) $[13,31]$. In CCR2-deficient APP transgenic mice, clearance of $A \beta$ is depressed [7]. Despite the permeation of $\mathrm{AD}$ brain by macrophages, clearance of neuritic plaques is randomly incomplete, suggesting functional heterogeneity of AD macrophages [13].

$\mathrm{AD}$ is a human disease with specific immune and biochemical defects [15], which have not been engineered in APP transgenic mice. To clarify the pathophysiology of A $\beta$ clearance in $\mathrm{AD}$, we examined $\mathrm{A} \beta$ clearance using human brain tissues and human macrophages, and observed that the $\mathrm{AD}$ innate immune system is defective in proper disposal of $A \beta$ in the brain.

\section{Materials and methods}

Antibodies and reagents

We stained macrophages using mouse anti-human CD68 (Dako, Carpinteria, CA) and goat anti-human CD68 (Santa Cruz Biotech, Santa Cruz, CA, USA). Neurons were stained with mouse anti-human neuronal nuclei (NeuN, Chemicon, Temecula, CA, USA); mouse anti-human microtubule associated protein 2 (MAP2, Sigma, St Louis, MO, USA); and rabbit anti-human neuron specific enolase (Immunostar, Hudson, WI, USA). To visualize $A \beta$ in brain tissue and in macrophages, we utilized rabbit anti-A $\beta$ 1-42 (COOH-terminal epitope) (Millipore, Billerica, MA, USA); mouse biotinylated anti-A $\beta$ 1-42 (COOH-terminal epitope) (Signet); rabbit anti-oligomer A11 (Biosource, Carlsbad, CA, USA), which recognizes $A \beta-42$ and $A \beta-40$ pre-fibrillar oligomers [22]; and rabbit anti-fibrillar OC, which stains A $\beta$ fibrils, as well as $\alpha$-synuclein fibrils and islet amyloid polypeptide fibrils [23]. To stain apoptotic markers, we used anti-caspase- $6,-7$, and -8 antibodies, which were raised in rabbits using catalytic subunits of the relevant autoprocessed recombinant caspases as immunogens (Burnham Institute, La Jolla, CA, USA) [24]. Secondary antibodies were anti-mouse, anti-rabbit, and anti-goat IgG's conjugated to Alexa Fluor 488, 555, and 647 (Invitrogen, Carlsbad, CA, USA). The reagents were monocyte chemotactic protein-1 (MCP-1) (PeproTech, Rocky Hill, NJ, USA); fluorescein isothiocyanate (FITC)-conjugated $A \beta$ (Anaspec, San Jose, CA, USA); fibrillar FITC-A $\beta$ and protofibrillar $\mathrm{A} \beta$ prepared by $\mathrm{M}$. Inayathullah; and ${ }^{14} \mathrm{C}$-labeled 
A $\beta$ from C. Glabe, UCI. A $\beta$ was used at $2 \mu \mathrm{g} / \mathrm{mL}$ in most experiments.

Patients and controls

A total of ten patients [mean age $76.9 \pm 5.8$ years, mean Mini-Mental State Exam (MMSE) score of $21.7 \pm 5.1]$ with a diagnosis of probable $\mathrm{AD}$ established by the National Institute of Neurological and Communication Disorders and Stroke/Alzheimer's Disease and Related Disorders Association criteria [29] were recruited into the study since 2004 through the University of California, Los Angeles (UCLA), Alzheimer's Disease Research Center under a UCLA Institutional Review Board-approved protocol. In addition, eight aged-matched control subjects (mean age $77.5+6.0$ years) and three young control subjects (ages 20, 21, 44) were recruited from UCLA personnel and families of patients.

\section{Isolation of PBMC's}

Peripheral blood mononuclear cells (PBMC's) were isolated from venous blood of the $\mathrm{AD}$ patients and control subjects by Ficoll-Hypaque gradient centrifugation as previously described [13]. Monocytes were purified using RosetteSep Monocyte Enrichment Cocktail (StemCell Technologies, Vancouver, BC, Canada) from PBMC's of normal subjects ("normal monocytes" or "normal macrophages") and AD patients ("AD monocytes" or AD macrophages").

Preparation of fibrils and protofibrils of $\mathrm{A} \beta(1-42)$

$\mathrm{A} \beta$ fibrils were prepared by dissolving $1 \mathrm{mg}$ of $\mathrm{A} \beta$ (1-42) peptide in $100 \mu \mathrm{L}$ of $10 \mathrm{mM} \mathrm{NaOH}$. The solution was diluted to a volume of $0.5 \mathrm{~mL}$ with milliQ water followed by addition of $0.5 \mathrm{~mL}$ of $10 \mathrm{mM}(2 \times)$ phosphate buffer $(\mathrm{pH}$ 7.4). The resulting solution was then centrifuged at $16,000 \times g$ for $10 \mathrm{~min}$. One-half milliliter of the resulting supernatant was transferred into a new tube and incubated at $37^{\circ} \mathrm{C}$ for 7 days. The fibrils were pelleted out by centrifugation for $10 \mathrm{~min}$ and the supernatant was transferred to another tube for protofibril isolation. The fibril pellet was washed thrice with MilliQ water and the resulting pellet thereafter resuspended in MilliQ water after each wash.

Protofibrils were isolated from the supernatant by filtering through a Centricon filter (molecular weight cutoff of $35 \mathrm{kDa}$ ) to remove any small oligomers and monomers and collecting the filtrate. The pellet was washed three times with MilliQ and then reconstituted and diluted with MilliQ water. A small aliquot of each sample was analyzed by amino acid analysis to determine the protein concentration. The samples were characterized by size exclusion chroma- tography and electron microscopy (Fig. 2). Fibrillar and protofibrillar $A \beta$ also was prepared in smaller amounts from FITC-A $\beta$.

Monocyte migration across a human blood-brain barrier model

A human blood-brain barrier model (BBB) model with primary human brain microvascular endothelial cells (BMVEC's) was constructed in a 24-well plate as described previously $[8,12]$. In the model, 50,000 BMVEC's in passages 4-8 coated either the upper surface ("regular model") or the lower surface of a porous membrane insert (Collaborative Biomedical Products, Bedford, MA, USA) ("reverse model") which rests above a well. Both the well and the membrane insert contained RPMI medium with $10 \%$ fetal bovine serum or $10 \%$ autologous serum.

In migration experiments, 250,000 monocytes from two control subjects (ages 74 and 78) and two AD patients (ages 80 and 84 with MMSE scores 20 and 23, respectively) were allowed to migrate across the BBB for $17 \mathrm{~h}$. The number of transmigrated cells was determined by triplicate cell counting in eight sections of a hemocytometer chamber. The inserts were washed gently with a buffer containing $0.1 \mathrm{M}$ sodium cacodylate plus $0.2 \mathrm{M}$ sucrose $\mathrm{X} 2$, then fixed with $3 \%$ glutaraldehyde in $0.1 \mathrm{M}$ sodium cacodylate buffer for $1 \mathrm{~h}$ at $25^{\circ} \mathrm{C}$ [26]. The cells were stored in this buffer at $4^{\circ} \mathrm{C}$, post-fixed with $1 \%$ osmium tetroxide at $4^{\circ} \mathrm{C}$, dehydrated in an ethanol series and embedded in plastic [27]. One-micron sections were stained with toluidine blue and examined by bright field and transmission electron microscopy.

$\mathrm{A} \beta$ phagocytosis and apoptosis by macrophages

Macrophages of four controls (ages 74, 74, 81, 90) and four AD patients (ages 70, 77, 82, 86 with MMSE scores 15, 27, 19, 27, respectively) were prepared in 8-well chamber slides as described [13]. The cultures were incubated with fibrillar or protofibrillar $A \beta$ for 3 days. Macrophage apoptosis was determined using the FLICA VAD-FMK polycaspases assay kit (Immunohistochemistry Technologies, Bloomington, MN, USA). This assay utilizes a membrane permeant, sulforhodamine B (SR)-labeled inhibitor targeted to all active caspases to covalently label apoptotic cells. Macrophage cultures were incubated with the FLICA apoptosis detection probe for $1 \mathrm{~h}$ at $37^{\circ} \mathrm{C}$ and then washed to remove any non-covalently bound probe from non-apoptotic cells. Cells were examined with an Olympus Bmax fluorescence microscope with $100 \times$ objective. Fluorescence density was determined by Image-Pro Plus 4.1 (Media Cybernetics, Silver Spring, MD). We examined the middle strip of each well for 6-9 consecutive fields with macrophages, analyzing the integrated optical density (IOD) of 
$\mathrm{A} \beta$ (green) and FLICA (red) per macrophage in three experiments for each group.

In a set of related experiments, control and $\mathrm{AD}$ macrophages were incubated with soluble FITC-A $\beta$ for $1 \mathrm{~h}$, or 3 , 5 , or 7, and apoptosis was detected using the FLICA assay. In some experiments, macrophages were incubated with soluble unconjugated $A \beta$ for $1 \mathrm{~h}$, washed twice, then incubated for 2, 4, or 6 days. Apoptosis was determined by the FLICA assay, and $\mathrm{A} \beta$ fibrils and oligomers were detected by the indirect technique using $\mathrm{OC}$ and $\mathrm{A} 11$ antibodies, respectively.

\section{ELISA assay of $A \beta$ clearance from monocytes}

Purified monocytes $(300,000$ per sample) were incubated with soluble $A \beta(2 \mu \mathrm{g} / \mathrm{mL})$ for $2 \mathrm{~h}$, washed four times, reincubated for the indicated number of days, and the amount of intracellular $A \beta$ remaining at each time point was determined $(0,1,2,3,5$, and 7 days). To measure the amount of intracellular $A \beta$, the cells were harvested into an ELISA lysis buffer (Invitrogen), supplemented with a protease inhibitor cocktail (Sigma) and assayed using the A $\beta$ 1-42 ELISA kit (Invitrogen) by spectrophotometry. Monocytes from four control subjects and three AD patients were tested.

\section{Brain tissues}

Frozen sections from the frontal lobe of two control subjects with no neuropathology (ages 23 and 37) and four $A D$ patients were provided by the UCLA Brain Bank. The AD brain sections were from: (1) a 62-year-old patient with Binswanger encephalopathy and scattered senile plaques in the entorhinal cortex and hippocampus; (2) a 64-year-old Braak stage VI patient; (3) a 69-year-old Braak stage VI patient; (4) an 82-year-old Braak stage VI patient with Lewy body disease.

\section{Co-incubation of PBMC's with brain tissues}

Frozen sections of post-mortem brain tissues of four $\mathrm{AD}$ patients and two controls were co-incubated with 500,000 PBMC's (from seven normal donors, ages 20, 21, 72, 74, 74,79 , and 85 years old) for 1 to 6 days in Dulbecco's Minimum Essential Medium (DMEM) with 10\% fetal calf serum, washed with PBS, fixed with $4 \%$ paraformaldehyde, and processed for immunofluorescence.

In some experiments, PBMC's were first pre-labeled with Qtracker 525, which distributes green Qdot nanocrystals in cytoplasmic vesicles, or CellTracker CMFDA (Invitrogen, Carlsbad, CA, USA), which undergoes an esterase reaction to produce a green fluorescent product in the cytoplasm. After isolation of PBMC's from blood, cells were incubated with Qtracker or CellTracker according to the manufacturer's recommendations, pelleted and washed twice with DMEM, and then incubated with tissues as above.

Immunofluorescence and confocal microscopy of brain tissues

Fixed tissues were permeabilized with $1 \%$ Triton X-100 and blocked with $1 \%$ bovine serum albumin (BSA) at $37^{\circ} \mathrm{C}$ for 30 min each. Brain sections were then incubated with various primary antibodies for $48 \mathrm{~h}$ at $4{ }^{\circ} \mathrm{C}$, washed with PBS, and incubated with appropriate secondary antibodies labeled with Alexa 488, Alexa 555, and Alexa 647 fluorophores for $1 \mathrm{~h}$ at $37^{\circ} \mathrm{C}$. A mixture consisting of $0.2 \%$ Triton $\mathrm{X}-100$ and $1 \%$ BSA was used as the diluent of both primary and secondary antibodies. As control staining, the sections were stained by secondary antibodies without primary antibodies. The preparations were examined using a Zeiss 510 Meta multiphoton confocal microscope or a Bio-Rad Laboratories MRC-1024 Es laser scanning confocal system attached to a Nikon E800 fluorescent microscope.

Statistical analysis

The data on monocyte migration and ${ }^{14} \mathrm{C}-\mathrm{A} \beta$ transport were analyzed by $t$ test and Mann-Whitney and Kruskall-Wallis tests.

\section{Results}

$A \beta$ uptake by monocytes inhibits monocyte emigration and $\mathrm{A} \beta$ export across $\mathrm{BBB}$

In the human BBB model, we compared the rate of migration by normal monocytes in both directions using either a regular model (blood chamber above apical side of BMVEC's) or a reverse model (brain chamber above abluminal side of BMVEC's). The rate was greater in the direction from brain to blood $(36.4 \pm 0.7 \%)$ compared to that from blood to brain $(13.6 \pm 2 \%)$. In the course of inflammation, chemokines stimulate and lipoxins inhibit leukocyte migration; to confirm the value of this model in replicating in vivo mononuclear cell migration, we used either the chemokine MCP-1 (CCL2) alone or both MCP-1 and lipoxin $\mathrm{A}_{4}$ together in the lower chamber. MCP-1 $(50 \mathrm{ng} / \mathrm{mL})$ increased monocyte migration from $0.4 \pm 0.8 \%$ to $6.5 \pm 0.2 \%$, and lipoxin $\mathrm{A}_{4}$ decreased this migration in a dose-responsive fashion from $6.5 \%$ with MCP-1 alone to $3.1 \pm 0.1 \%\left[0.1 \mathrm{nM}\right.$ (lipoxin $\mathrm{A}_{4}$, plus $50 \mathrm{ng} / \mathrm{mL} \mathrm{MCP}-1)], 1.6 \pm 0.1 \%(1 \mathrm{nM})$, and $0.8 \pm 0.1 \%$ 
(10 $\mathrm{nM})$. We then investigated $\mathrm{A} \beta$ export using the reverse model with the chemokine MCP-1 in the lower chamber. As expected, the emigration of monocytes was highest $(77,250 \pm 9,032)$ in the presence of MCP-1 in the lower chamber and lowest without MCP-1 (5,375 \pm 411$)$. When ${ }^{14} \mathrm{C}-\mathrm{A} \beta(10,000 \mathrm{DPM}$ or $1 \mu \mathrm{g} / \mathrm{mL})$ was placed in the brain chamber, monocyte emigration was reduced by $62 \%$ (from $77,250 \pm 9,032$ to $29,600 \pm 8,988$ ) (Table 1). Furthermore, maximal ${ }^{14} \mathrm{C}-\mathrm{A} \beta$ export across the blood brain barrier was found in the absence of monocytes (mean \pm SEM, $1,960 \pm 198 \mathrm{CPM})$. The presence of monocytes in the upper chamber diminished export by $13 \%$ (to $1,712 \pm 94$ CPM), and monocytes in the upper chamber with MCP-1 in the lower chamber reduced the export by $26 \%$ $(1,456 \pm 168 \mathrm{CPM}, P<0.05)$ (Table 1$)$. In two subsequent experiments with two different control/AD subject pairs, both $\mathrm{AD}$ and normal monocytes were inhibited in migration by A $\beta$-loading (SI Fig. 1).

To visualize monocyte migration, the BBB models from the wells with $A \beta$ [either fibrillar (Fig. 1a) or soluble (Fig. 1b)] or without $A \beta$ (Fig. 1c, d) were fixed, sectioned, stained using toluidine blue, and examined by light and transmission electron microscopy. Large macrophages with vacuoles suggestive of uploaded $A \beta$ were adherent to thin endothelial cells (Fig. 1a, b). In the wells without $A \beta$, monocytes freely migrated across the BBB model and, the endothelial cells displayed tall cytoplasm and abundant mitochondria (Fig. 1c, d). Thus macrophages loaded with $A \beta$ adhere to endothelial cells and are inhibited in emigration across the BBB.

Normal monocytes bind and clear more $\mathrm{A} \beta$ in comparison to $\mathrm{AD}$ monocytes

When tested in bulk by $\mathrm{A} \beta$ ELISA, normal monocytes uploaded more $\mathrm{A} \beta$ and cleared it more rapidly than $\mathrm{AD}$ monocytes (Fig. 2). After the initial $2 \mathrm{~h}$ incubation, control monocytes bound an average of $256 \mathrm{pg} / \mathrm{mL} \mathrm{A} \beta$, compared to $112 \mathrm{pg} / \mathrm{mL}$ by $\mathrm{AD}$ monocytes. After thorough washing and re-incubation for $24 \mathrm{~h}$, control monocytes had cleared on average $54 \%$ of the uploaded A $\beta$ while AD monocytes had degraded only $28 \%$.

Table 1 A $\beta$ uptake by monocytes in the brain chamber inhibits monocyte migration and A $\beta$ export into the blood chamber

\begin{tabular}{|c|c|c|c|c|c|}
\hline \multirow[t]{2}{*}{ Treatment } & \multicolumn{2}{|c|}{ Brain Chamber } & \multicolumn{3}{|c|}{ Blood Chamber } \\
\hline & Monocytes & ${ }^{{ }^{14} \mathrm{C}-\mathrm{A} \beta(\mathrm{CPM})}$ & $\mathrm{MCP}-1(\mathrm{nM})$ & Monocytes & ${ }^{14} \mathrm{C}-\mathrm{A} \beta(\mathrm{CPM})$ \\
\hline A & 250,000 & - & 20 & $77,250 \pm 9,032$ & - \\
\hline $\mathrm{B}$ & - & 10,000 & - & - & $1,960 \pm 198$ \\
\hline $\mathrm{C}$ & 250,000 & 10,000 & - & $13,750 \pm 3,774$ & $1,712 \pm 94$ \\
\hline $\mathrm{D}$ & 250,000 & 10,000 & 20 & $29,600 \pm 8,998$ & $1,456 \pm 168$ \\
\hline $\mathrm{E}$ & 250,000 & - & - & $5,375 \pm 411$ & - \\
\hline
\end{tabular}

A total of 250,000 monocytes and/or 10,000 CPM of ${ }^{14} \mathrm{C}-\mathrm{A} \beta$ were placed into the upper (brain) chamber of a blood-brain barrier model with or without MCP-1 in the lower (blood) chamber. Monocytes and ${ }^{14} \mathrm{C}-\mathrm{A} \beta$ were measured in the lower chamber after $24 \mathrm{~h}$

Fig. 1 MM's with $A \beta$ adhere to brain endothelial cells, whereas MM's without $A \beta$ transmigrate. Monocytes, which were exposed to $\mathrm{A} \beta(2 \mu \mathrm{g} / \mathrm{mL})$ [fibrillar (a) and soluble (b)] in the upper chamber and attracted for migration by MCP-1 $(50 \mathrm{ng} / \mathrm{mL})$ in the lower chamber, adhered to brain endothelial cells, which appeared flat. Monocytes, which were not exposed to $A \beta$, migrated freely across endothelial cells (c) (light microscopy, $\times 100$ ) and the endothelial cells exposed to migrating monocytes became tall and disorganized with a monocyte migrating to the abluminal side (d) (transmission electron microscopy, $\times 22,000$ )
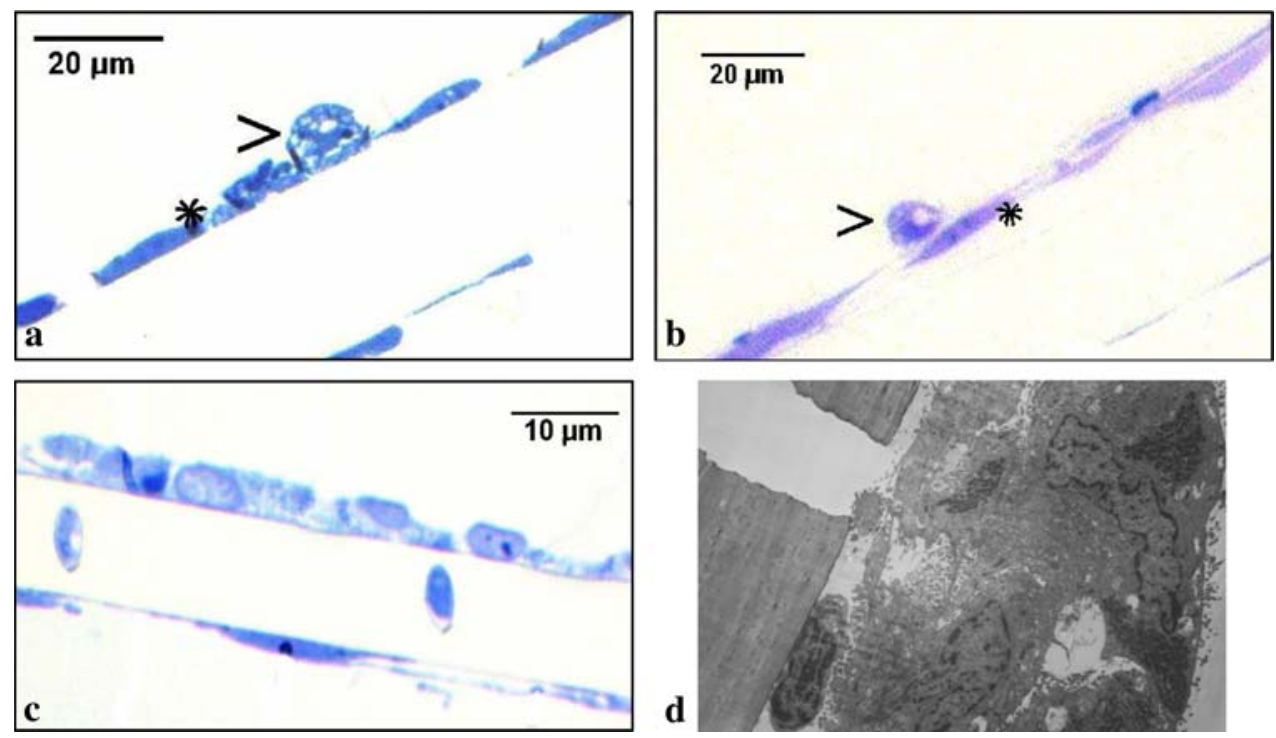


\section{Controls}
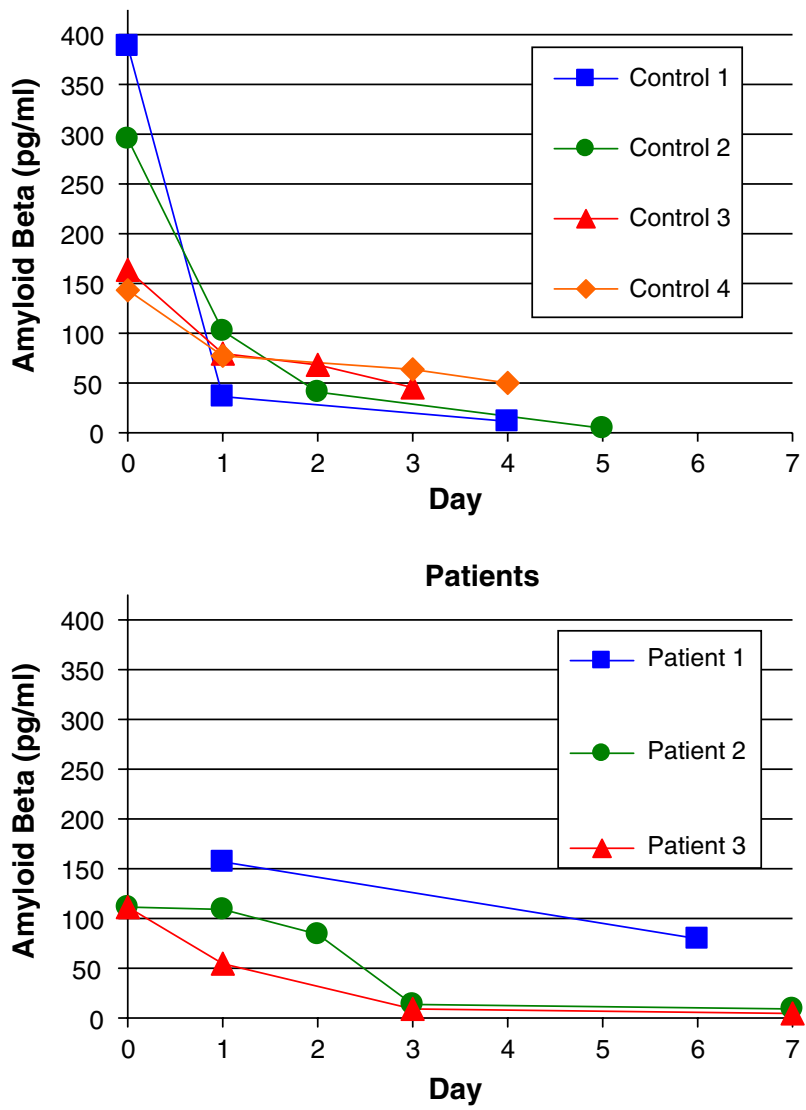

Fig. 2 Uptake and removal of $A \beta$ by normal monocytes are greater compared to AD monocytes. Monocytes were exposed to $\mathrm{A} \beta(2 \mu \mathrm{g} / \mathrm{mL})$ for $2 \mathrm{~h}$, washed, and incubated for the indicated number of days when $\mathrm{A} \beta$ was measured by the ELISA assay. Control monocytes (a) showed higher uptake of $\mathrm{A} \beta$ after 2-h exposure than $\mathrm{AD}$ monocytes (b) and similarly showed more rapid removal of $A \beta$ in comparison to $A D$ monocytes

Fibrillar, protofibrillar, and soluble $\mathrm{A} \beta$ induce apoptosis of $\mathrm{AD}$ macrophages

After 3-day exposure to fibrillar A $\beta$ (Fig. 3a), AD macrophages displayed large fibrils and showed a robust apoptotic signal, whereas in normal macrophages $\mathrm{A} \beta$ was found in small fragments and the macrophages showed a low apoptotic signal (Fig. 4a). Similarly, after 3-day exposure to protofibrillar $\mathrm{A} \beta$ (Fig. 3b), AD macrophages displayed a robust apoptotic signal, whereas normal macrophages had almost no apoptotic signal although they showed a high uptake of protofibrils (Fig. 4b).

After only 1-h exposure to soluble FITC-A $\beta$, an apoptotic FLICA signal became visible in $\mathrm{AD}$, but not control, macrophages; by 5 days $\mathrm{AD}$ macrophages were seen to be disrupted (Fig. 5a). In a follow-up experiment AD macrophages which were incubated with soluble $A \beta$ for $1 \mathrm{~h}$, washed, and re-incubated for 4 or 6 days demonstrated a strong apoptotic signal and lysed and heterogeneously contained and released oligomeric and fibrillar $\mathrm{A} \beta$ (Fig. 5b). In comparison, control macrophages showed a weak FLICA signal, intracellular $A \beta$ decreased and the cells remained intact.

To explore macrophage clearance of $A \beta$ from $A D$ brain, we first examined the distribution of $A \beta$ assemblies in $A D$ brain sections.

Soluble and oligomeric $A \beta$ are present in neurons and macrophages, and fibrillar $A \beta$ in plaques and congophilic microvessels

In $\mathrm{AD}$ brain tissues, $\mathrm{A} \beta$ was detected in neurons in a patchy but distinct fashion using immunofluorescence with antiA $\beta$ 1-42 (COOH terminal) (Fig. 6a) or anti-oligomer antibodies (Fig. 6b). Fibrillar $A \beta$ was detected in neuritic plaques and brain vessels using the OC antibody; CD68positive cells infiltrated plaques and vessels (Fig. 6c). Clusters of macrophages, which were loaded with oligomeric $A \beta$ (Fig. 6d), abutted and infiltrated the wall of brain vessels and displayed activated caspases: initiator caspase-6, and effector caspases -7 and -8 , indicating their apoptosis (Fig. 6e, f, g). The brain vessels displayed fibrillar (Fig. 6c) but not oligomeric $A \beta$ (Fig. 6d). Unstained AD tissues, as well as tissues incubated with secondary but not primary antibodies, were inspected by fluorescence microscopy and their weak fluorescent signal due to autofluorescence was easily distinguished from the specific signal in preparations stained with both primary and secondary antibodies. In addition, control brain tissues did not disclose many infiltrating macrophages.

Monocytes upload soluble and oligomeric A $\beta$ in neurons

To experimentally investigate the brain clearance of $A \beta$, we co-incubated AD brain sections with control PBMC's for 3 days. Examination of these tissues by confocal microscopy showed monocytes (green) colocalizing in a patchy fashion with neurons (red) and uploading oligomeric $A \beta$ (blue). The soma of the monocytes was found in higher z-sections compared to the soma of the neurons suggesting intrusion of these monocytes into neurons from above. In midsections, neurons, monocytes, and $A \beta$ all colocalized (Fig. 7a). In addition, after $24 \mathrm{~h}$ incubation with AD brain sections, CellTracker and Qtracker prelabeled monocytes were seen to co-localize with neurons, confirming intrusion of exogenous monocytes into neurons (Fig. 6b). We did not notice obvious differences in clearance of $A \beta$ between the monocytes of younger and elderly control subjects but did not analyze these differences. We also stained AD brain tissues co-incubated without exogenous monocytes but did not find CD68 positive monocytes intruding into neurons. 
Fig. 3 Fibrillar and protofibril$\operatorname{lar} \mathrm{A} \beta$ (1-42). Five microlitre of samples were spotted on a glowdischarged, carbon-coated

Formvar grid and incubated for 5 min, washed with distilled water, fixed with $2.5 \%$ glutaraldehyde, stained with a $1 \%(\mathrm{w} / \mathrm{v})$ aqueous uranyl acetate solution, and examined using a JEOL transmission electron microscope
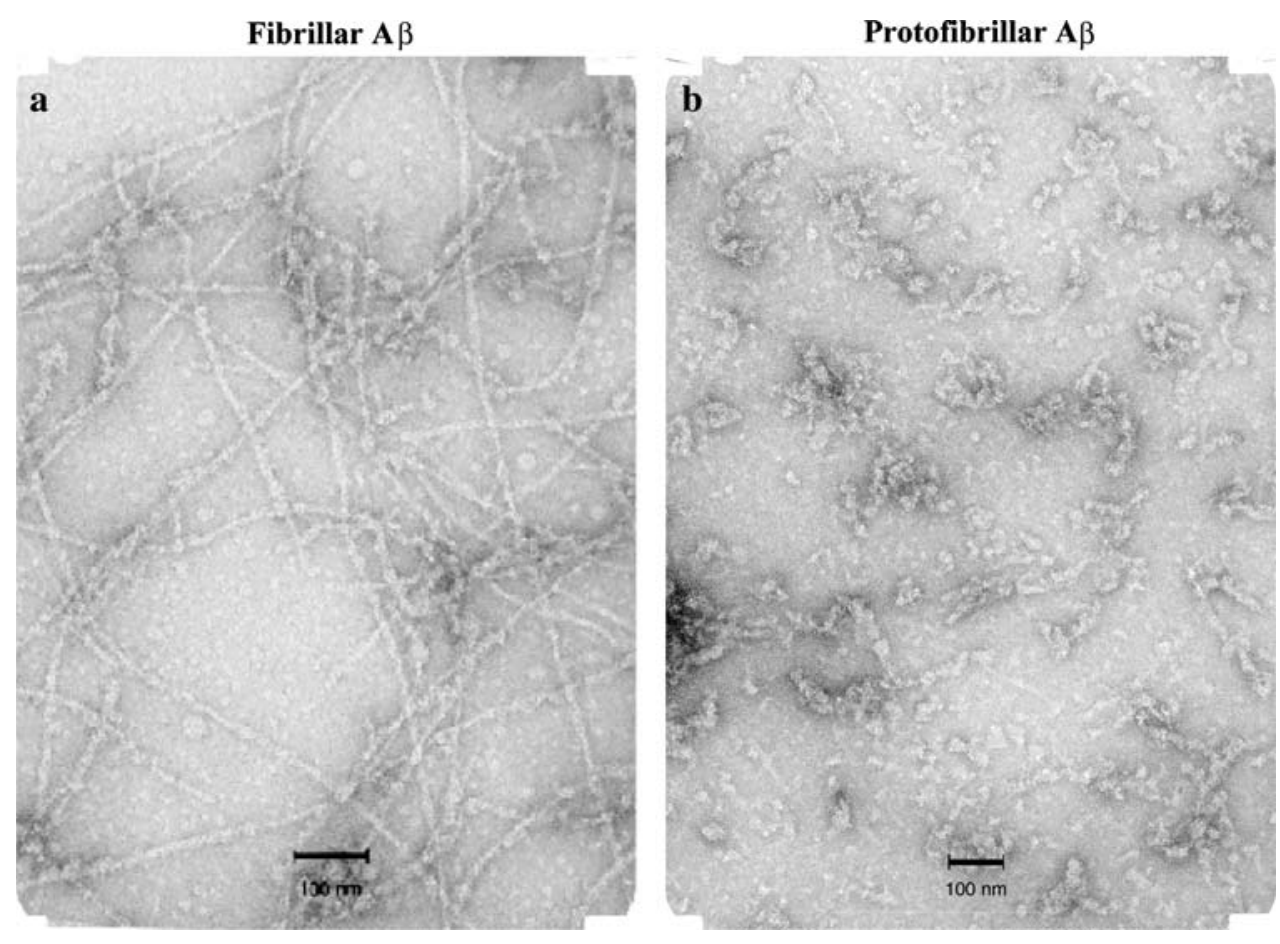

\section{Discussion}

In transgenic animal models of $\mathrm{AD}, \mathrm{A} \beta$-induced pathology seems to be upstream of tau and is considered the primary mechanism [33]. We have attempted to glean the mechanisms responsible for clearance of $A \beta$ from human brain by comparing the results of morphologic and experimental investigations. Although emigration of macrophages across the BBB has been infrequently investigated, macrophage immigration is well known in HIV-1 encephalitis and is becoming accepted in AD [11]. Our results in the model BBB exclude the emigration of $A \beta$-engorged macrophages as a mechanism of $A \beta$ clearance since these adhered to the endothelium and were inhibited in emigration. Thus the fate of $A \beta$ in aging brain seems to depend upon its handling and degradation inside the BBB.

Our observations suggest that oligomeric $A \beta$ in perivascular macrophages may contribute to the fibrillar $A \beta$ in congophilic vessels. AD macrophages are defective in uptake of $A \beta$ (Fig. 3), yet are particularly susceptible to apoptosis from all assembly states of $A \beta$ (Figs. 4, 5), contrasting with the ability of control macrophages to phagocytize $A \beta$ [15] and to resist apoptosis (Figs. 4, 5). The phagocytic propensity of $\mathrm{AD}$ macrophages is compounded by their low clearance of $A \beta$ (Fig. 2). These deficits might be related to downregulation of transcription of certain genes, including MGAT-3 and Toll-like receptors [15].

In $\mathrm{AD}$ brain, macrophages are apoptotic through activation of caspases $-6,-7$, and -8 (Fig. 6e, f, g), and they abut and infiltrate congophilic microvessels from the outside
[11] (Fig. 6d), in agreement with the assembly of $A \beta$ fibrils outside of the basal lamina [52]. Immunohistochemical studies of cerebral amyloid angiopathy (CAA) revealed its association with a significant increase and activation of macrophages in leptomeningeal and cortical vesselsimplicating a central role for macrophages in amyloid angiopathy [53]. Furthermore, the BBB in AD brain is impaired [11] by immigrating macrophages (Fig. 1d), thus allowing leakage of plasma proteins into the brain and further aggravation of angiopathy. Taken together, AD macrophages loaded with oligomeric $A \beta$ seem to suffer apoptosis, disintegrate and release oligomeric and fibrillar $A \beta$ into the wall of congophilic vessels. Still, it is important to recognize that although phagocytosis of $A \beta$ is generally greater in control monocytes compared to $\mathrm{AD}$ monocytes, this is a multifactorial and heterogeneous effect, and monocytes of some aged control subjects occasionally demonstrate inferior innate immunity [15] and phagocytosis of $\mathrm{A} \beta$ (SI Fig. 1).

Proposed mechanisms for the pathogenesis of CAA have included production of $A \beta$ by myocytes in vessel walls [51], derivation of $A \beta$ from blood or cerebrospinal fluid, and, more recently, deposition of $A \beta$ from interstitial fluid being drained from the central nervous system [49]. In APP-transgenic mice, amyloid angiopathy developed specifically in areas of the brain that over-produce $A \beta$, suggesting that brain, as opposed to blood, is the major source of $A \beta$ [44]. In mice, tracers were injected intracerebrally and found to be distributed, similarly to $A \beta$, within the basement membranes of intracerebral capillaries and arteries, and in leptomeningeal arteries [3]. Interestingly, within $24 \mathrm{~h}$ of injection the tracers 
Fig. 4 Fibrillar and protofibril$\operatorname{lar} \mathrm{A} \beta$ induce apoptosis of $\mathrm{AD}$ macrophages. After overnight exposure to fibrillar (a) or protofibrillar $\mathrm{A} \beta(2 \mu \mathrm{g} / \mathrm{mL})(\mathbf{b})$, normal macrophages displayed a low apoptotic FLICA signal (red) but a high uptake of protofibrillar A $\beta$ (green), whereas AD macrophages showed a robust FLICA signal and a high uptake of large fibrils (yellow or white due to spectral bleed-through of FITC) but low uptake of protofibrils. FLICA signal (red), protofibrillar or fibrillar $\mathrm{A} \beta$ (green) (duplicate images, fluorescence microscopy, $\times 100$ ). Charts show the mean IOD of FLICA and $\mathrm{A} \beta$ with error bars indicating standard error of mean a
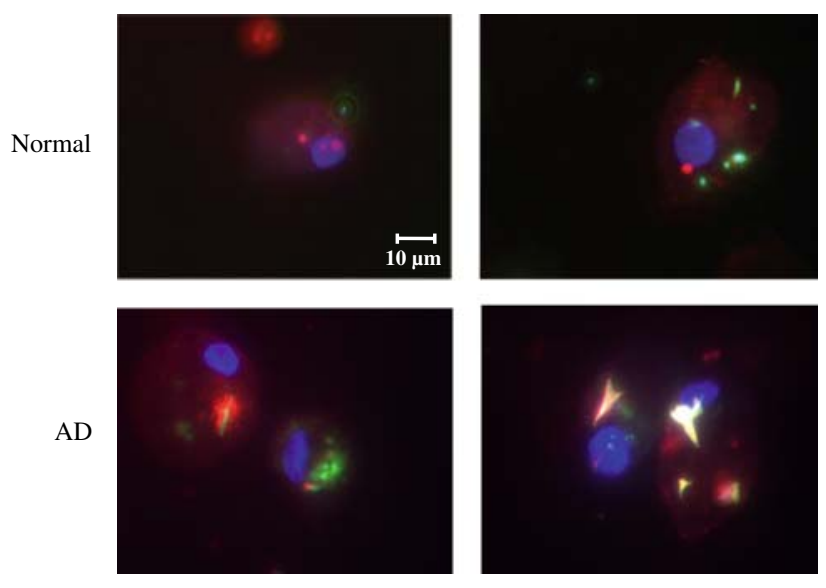

b
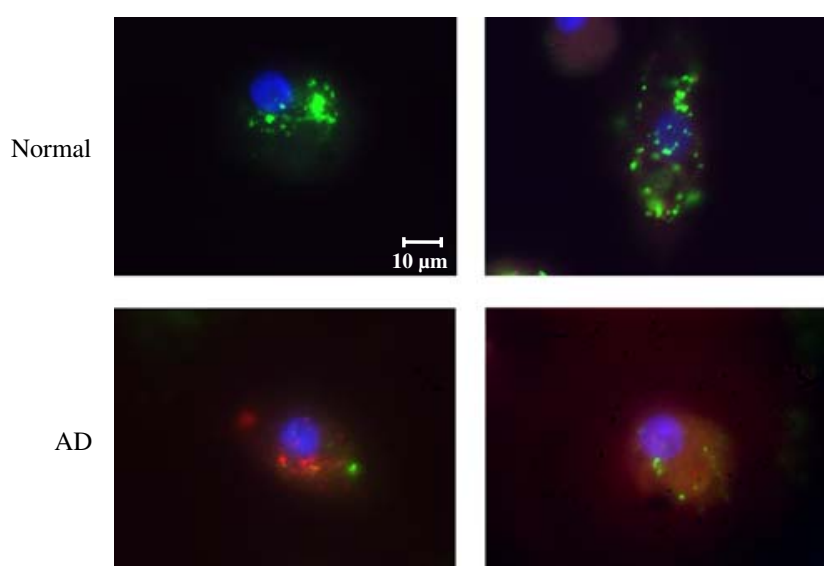

FLICA signal per macrophage
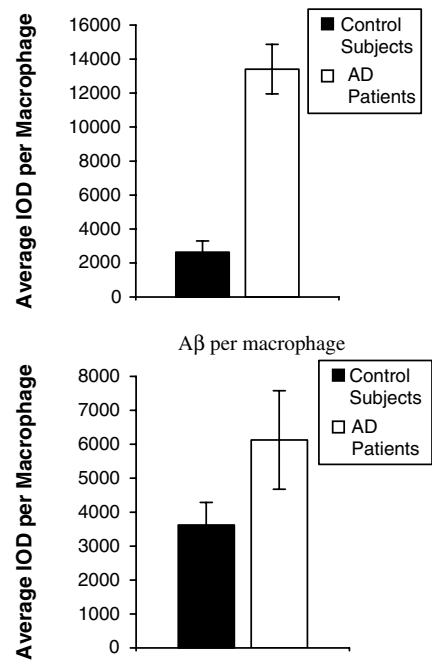

FLICA signal per macrophage
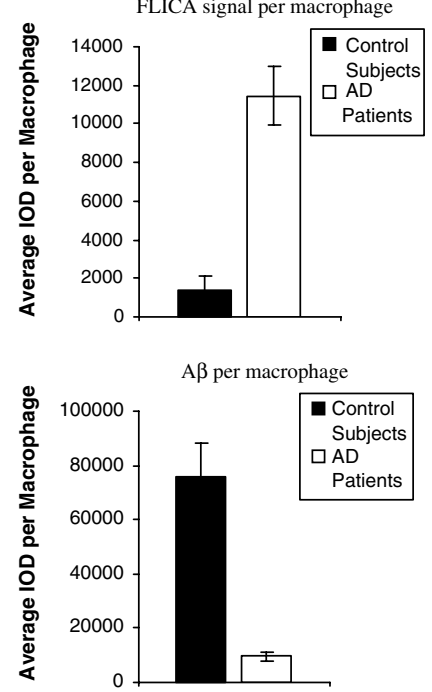

were located in perivascular macrophages and these cells remained in brain microvessels, experiencing limited migration. Thus both drainage of the interstitial fluid and shuttling of $A \beta$ by macrophages seem to lead to entrapment of $A \beta$ in perivascular macrophages.

The results of the experimental co-culture of normal subjects' monocytes with $\mathrm{AD}$ brain tissues show intrusion by these monocyte/macrophages into neurons and uploading of oligomeric $A \beta$, suggesting a protective neuronal mechanism by the normal innate immune system. However, AD monocyte/macrophages seem to be defective in such protection of neurons [15]. Although we have not investigated this mechanism by electron microscopy of AD brain tissues, we have observed that macrophages and monocytes exposed to $A \beta$ in vitro develop prolific microvilli and larger dendrites, which could reach into neurons and upload $A \beta$ [15].

In animal models of amyloidosis, microglia were first noted for their proinflammatory role [1]. Microglia of APOE4 transgenic mice produced more nitric oxide compared to
APOE3 transgenic mice [5]. Subsequently, microglia were found to provide clearance of $\mathrm{A} \beta$ and were assisted in clearing $\mathrm{A} \beta$ deposits by antibodies [2] and by complement opsonization [16, 45, 46]. Clearance of $\mathrm{A} \beta$ was recognized to include two phases: the first mediated by antibodies and the second by microglia and antibodies [50]. However, in triple transgenic APP-thymidine kinase mice, bone marrow-derived rather than resident microglia restricted amyloid deposits as shown by ganciclovir destruction of microglia [36].

However, human brain disorders involve both microglial activation and macrophage recruitment [40]. In AD brain, the initial inflammatory signal is induced by microglia [1] and neuronal chemokine RANTES. These stimuli attract large macrophages (clearly not resembling ramified microglia) to migrate across brain microvessels and invade neuritic plaques in AD brain [11]. Enzyme studies mitigate against the role of microglia in $A \beta$ clearance since, in comparison to macrophages, degradation of $A \beta$ by microglia is poor due to defective lysosomal enzymes [28]. 
Fig. 5 Soluble $A \beta$ induces apoptosis of $\mathrm{AD}$ macrophages and release of oligomeric and fibrillar $\mathrm{A} \beta$. a After incubation with FITC A $\beta(2 \mu \mathrm{g} / \mathrm{mL}), A D$ macrophages displayed a significantly stronger apoptotic FLICA signal (red) compared to control macrophages. AD macrophages heterogeneously lysed by 5 days (fluorescence microscopy, $\times 40$ ). b $\mathrm{AD}$ macrophages were incubated with soluble $A \beta(2 \mu \mathrm{g} / \mathrm{mL})$ for $1 \mathrm{~h}$, washed with PBS, incubated for 4 or 6 days, and stained with FLICA (red) and anti-oligomeric or anti-fibrillar antibodies (green). After 4-day incubation, $A \beta$ oligomers and fibrils are visible within the apoptotic macrophages, and by 6 days the cells appear disrupted. $A \beta$ oligomers diffused from the lysed macrophages whereas the denser $A \beta$ fibrils remained stuck in place on the glass slides (fluorescence microscopy, $\times 100$ )
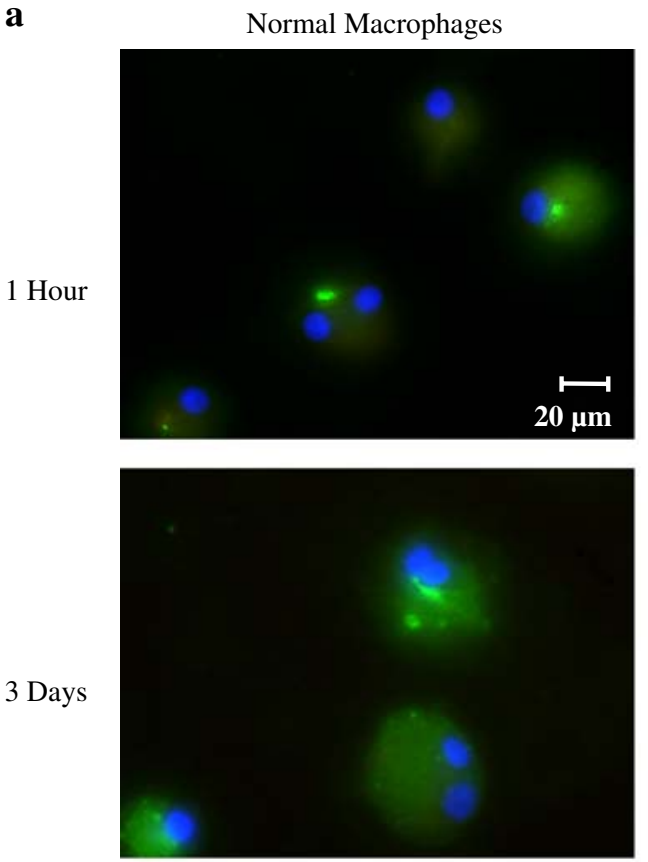

5 Days

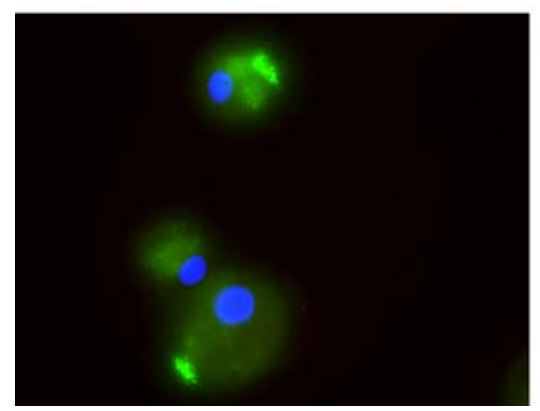

b

AD Macrophages

Oligomeric $A \beta$
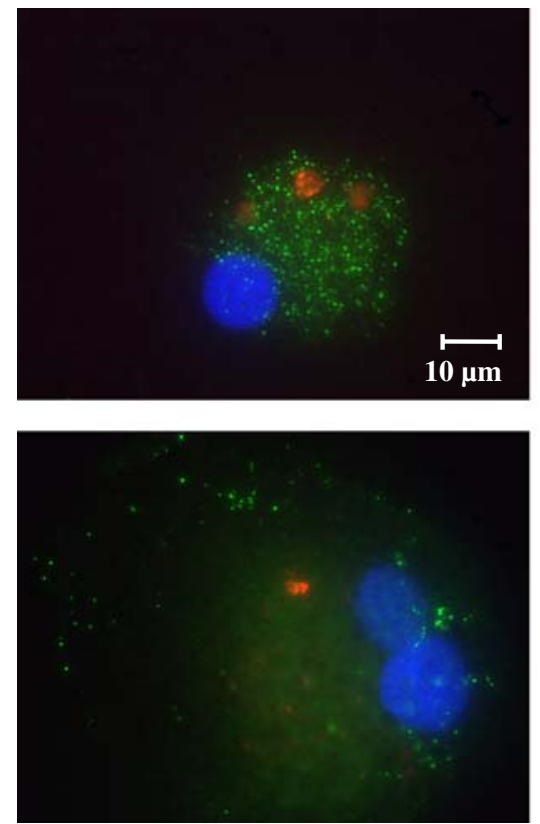
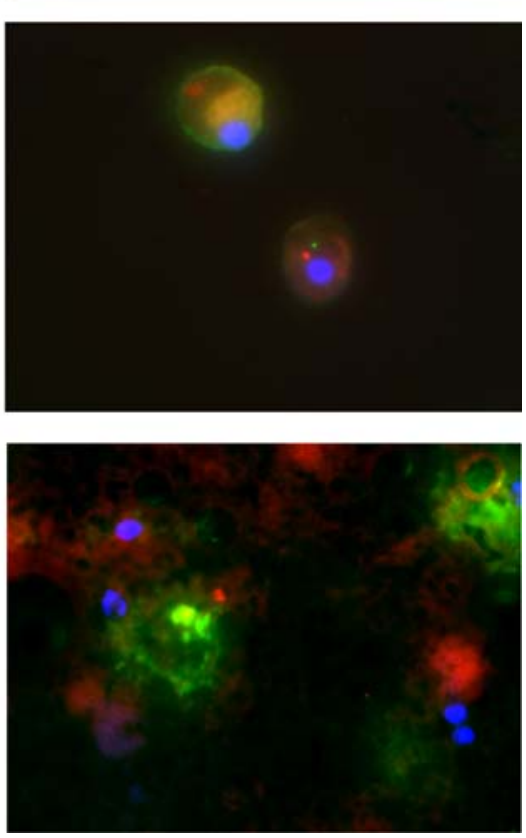

AD Macrophages

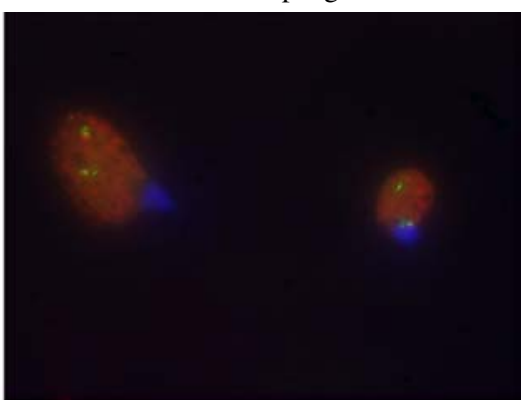

Fibrillar $\mathrm{A} \beta$
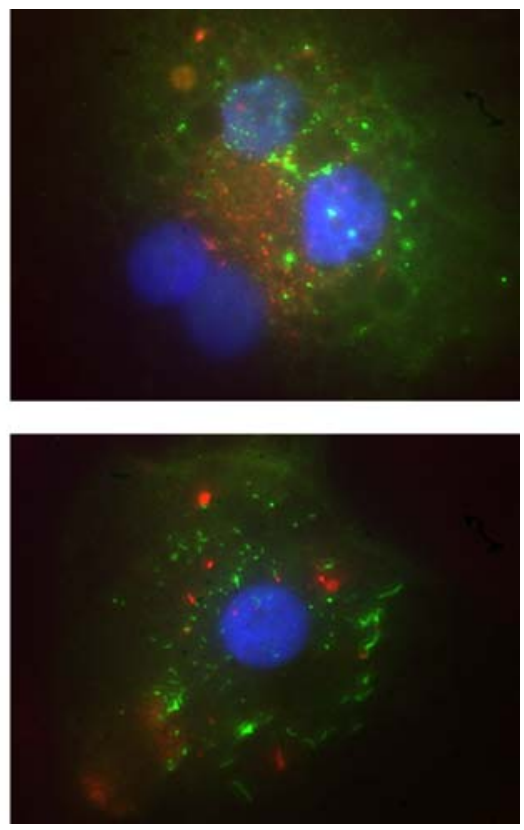
Fig. $6 A \beta$ assemblies in AD

brain: oligomeric and soluble

$A \beta$ is found in neurons and perivascular apoptotic macrophages, and fibrillar $A \beta$ in neuritic plaques and vessels. AD brain tissues show monomeric (a) and oligomeric $A \beta(b)$ in neurons in a patchy fashion, fibrillar $A \beta$ in plaques and microvessel walls $(\mathbf{c})$, and oligomeric $\mathrm{A} \beta$ in perivascular macrophages (d). Perivascular macrophages display activated caspases $-6,-7$, and -8 $(\mathbf{e}, \mathbf{f}$, and $\mathbf{g})$. Red soluble $\mathrm{A} \beta$, oligomeric $\mathrm{A} \beta$, fibrillar $\mathrm{A} \beta$, and activated caspases. Green neurons and macrophages. Blue nuclei. (a-c, e: $\times 40$ objective with Zeiss 510 Meta confocal microscope; $\mathbf{d}: \times 60$ objective with Bio-Rad Laboratories MRC1024 Es confocal system; f-g: $\times 40$ objective with Olympus Bmax fluorescence microscope) $\mathbf{a}$

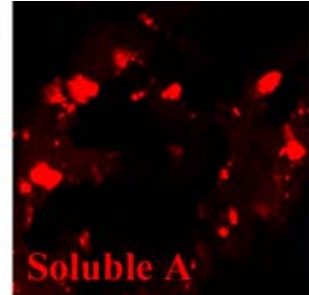

b

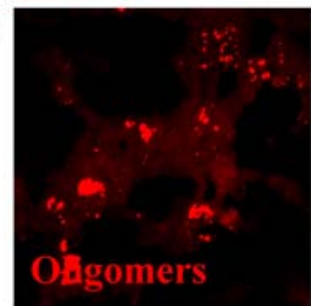

c

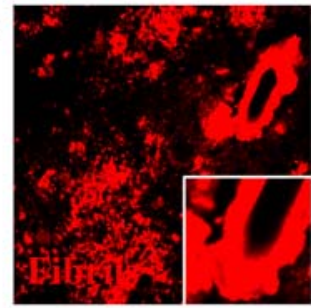

d

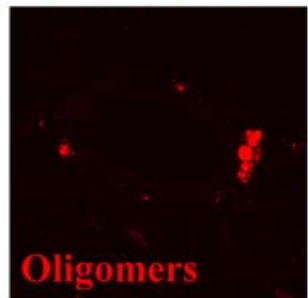

e

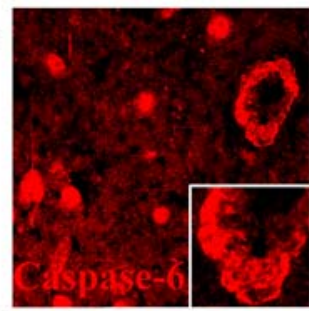

f

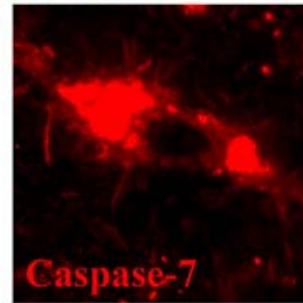

g

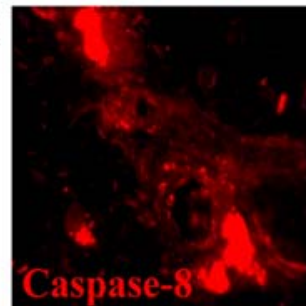

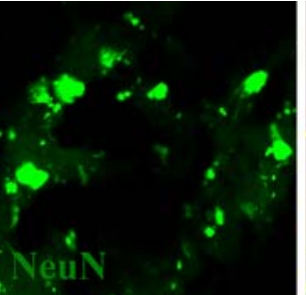
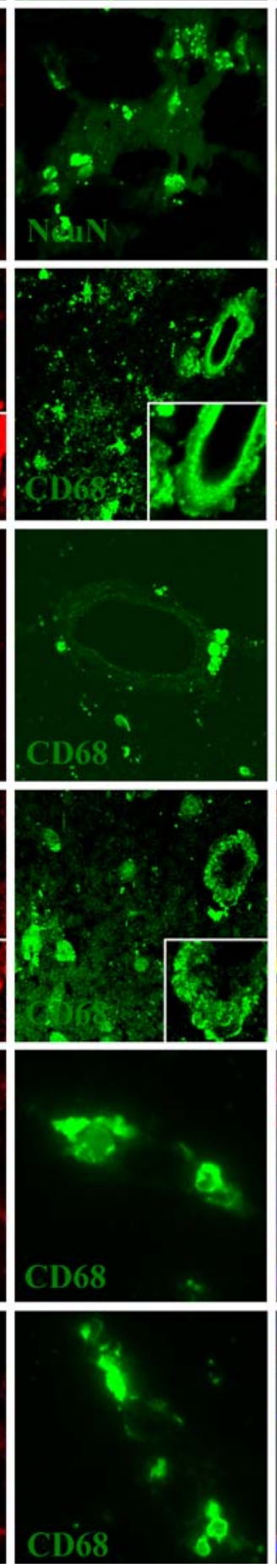
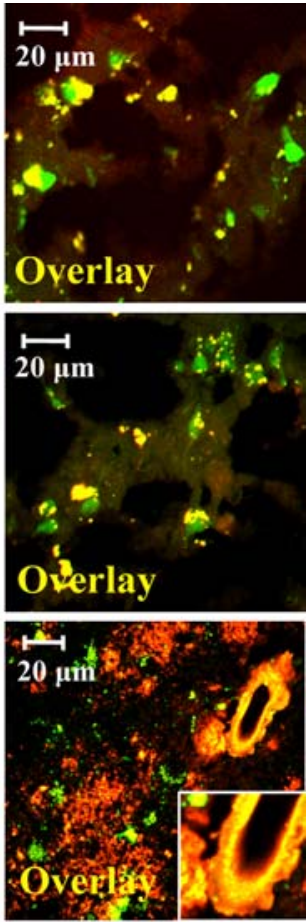

$\longmapsto$

$20 \mu \mathrm{m}$

$\therefore$

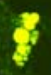

Overlay
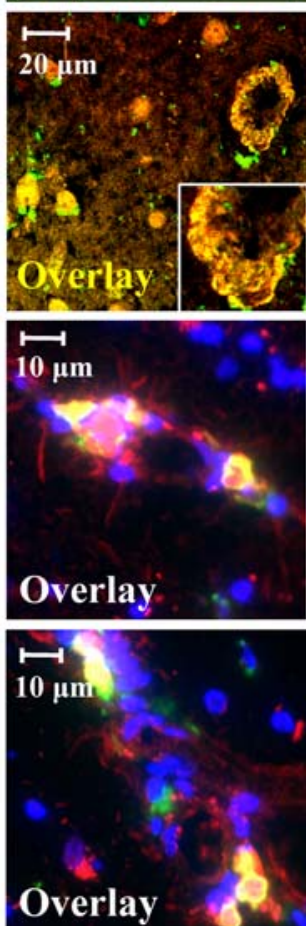
Fig. 7 In vitro clearance of $A \beta$ from $\mathrm{AD}$ brain: normal monocytes intrude and upload oligomeric $A \beta$ from neurons. a Brain tissue was co-incubated with 500,000 normal PBMC's for 3 days, stained and examined by a Zeiss 510 Meta confocal microscope $(\times 40)$. The soma of macrophages is visible in the top sections co-localized with oligomeric A $\beta$ (blue-green). Consecutively lower sections show higher densities of neurons ( $r e d$ ) with less CD68 (green) present. The yellow and white patches within neurons show intrusion of macrophages within neurons and phagocytosis of $A \beta$. Macrophages stained with anti-CD68 (green), oligomeric $\mathrm{A} \beta$ with anti-oligomer A11 (blue), and neurons with NeuN (red). (b and c) Brain tissue was co-incubated for $24 \mathrm{~h}$ with control PBMC's prestained with either CellTracker CMFDA (b) or Qtracker 525 (c), stained to visualize neurons, and examined with a Bio-Rad Laboratories MRC-1024 Es confocal system $(\times 60)$. Round monocytes (green) decorate neurons $(r e d)$. Insets in $\mathbf{b}$ and $\mathbf{c}$ show details of decoration of neurons (red) by monocytes (green)

\section{$\mathbf{a}$}
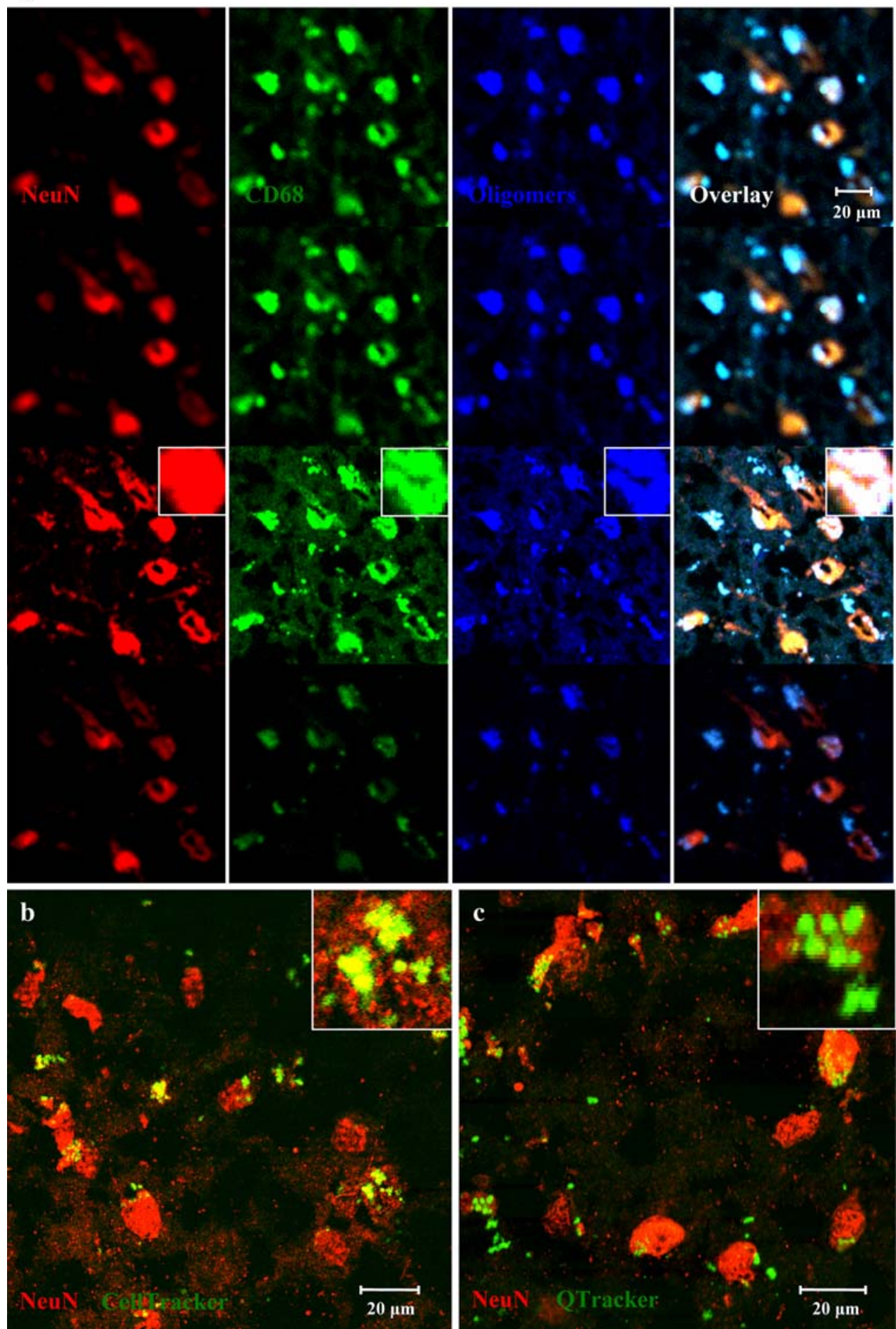

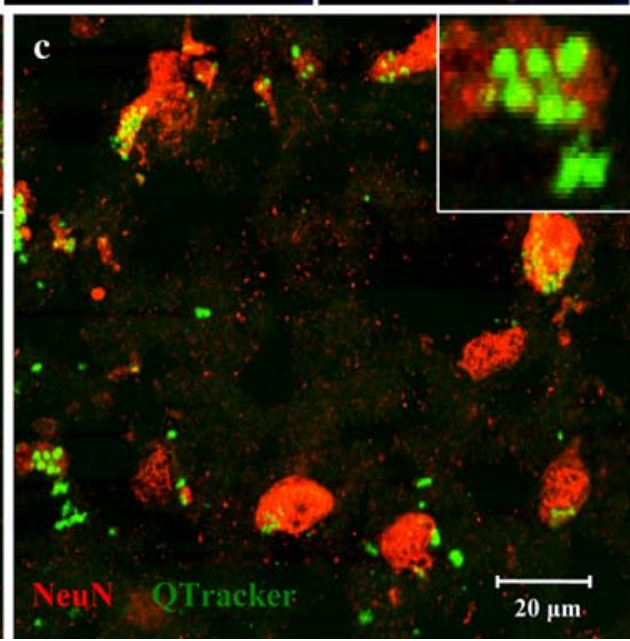

The alternative emphasis on treating brain amyloidosis or inflammation has led to two different therapeutic strategies in $\mathrm{AD}$ : $\mathrm{A} \beta$ vaccination or anti-inflammatory drugs. In AD patients, a delicate balance between macrophage phagocytosis and microglial inflammation appears to be disturbed, leading to decreased phagocytosis and degradation, and increased inflammation. We propose that the innate immune clearance of $\mathrm{A} \beta$ in $\mathrm{AD}$ brain involves shuttling of oligomeric $\mathrm{A} \beta$ by $\mathrm{AD}$ macrophages from neurons to perivascular locations, apoptotic death of these macrophages, $A \beta$ spillage into the vessel wall, and seeding of congophilic angiopathy (Fig. 8). We also speculate that brain amyloidosis may be cleared by stimulating AD macrophages using curcuminoids which increase phagocytosis [14, 15, 54], and other approaches which enhance resistance to apoptosis and decrease inflammation. 
Fig. 8 Congophilic angiopathy immunopathogenesis. $A \beta$ is produced in neurons by cleavage of the amyloid-precursor protein (APP) by the $\beta$ - and $\gamma$-secretases, releasing $A \beta$, which is re-uptaken into neurons and becomes oligomeric. Blood-borne monocytes (1) are attracted to neurons by chemokines produced by neurons (e.g. RANTES), intrude into neurons and neuritic plaques (2), and upload oligomeric $A \beta$ from neurons and fibrillar $A \beta$ in neuritic plaques. However, AD monocyte/macrophages (3) are heterogeneously deficient in $\mathrm{A} \beta$ clearance (uptake and degradation), and have deficient MGAT-III transcription and increased activation of caspases leading to their apoptosis. Some AD macrophages loaded with $A \beta$ migrate to vessels (4) but are unable emigrate due to their engorgement with $\mathrm{A} \beta$ and consequently undergo apoptosis. Simultaneously, soluble and oligomeric $A \beta$ have undergone peptide assembly into fibrillar $A \beta$, which is discharged into the vessel wall (5). Furthermore, congophilic angiopathy induces oxidative stress to neurons, and inflammatory cytokines produced by microglia potentiate neuronal damage

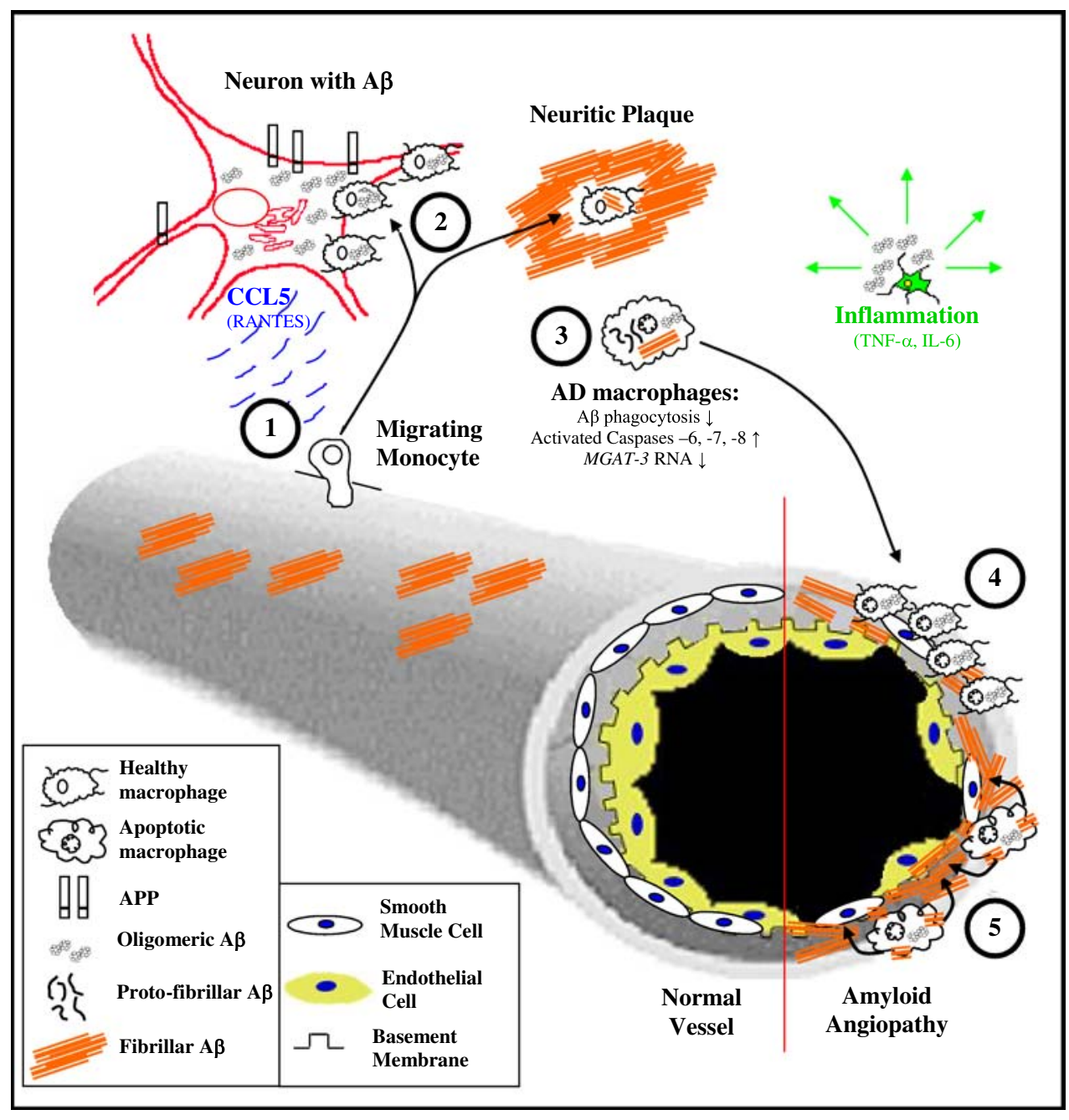

Acknowledgments We thank J. Sayre for statistical analysis, S. Krajewski (Burnham Institute) for antibodies to activated caspases, B. Carter for nursing assistance with collection of blood specimens from patients and control subjects, B. Magrys for cutting sections of the blood-brain barrier model, $\mathrm{C}$. Glabe for providing ${ }^{14} \mathrm{C}-\mathrm{A} \beta$ and $\mathrm{A} 11$ and OC antibodies, and C. Serhan for lipoxin $\mathrm{A}_{4}$. The UCLA Brain Bank provided the brain tissues for immunostaining.

Conflict of interest statement This work was supported by the Alzheimer's Association, MPBio Ltd (MF) and NIH grant AG027818 (DBT).

Open Access This article is distributed under the terms of the Creative Commons Attribution Noncommercial License which permits any noncommercial use, distribution, and reproduction in any medium, provided the original author(s) and source are credited.

\section{References}

1. Akiyama H, Barger S, Barnum S, Bradt B, Bauer J, Cole GM, Cooper NR, Eikelenboom P, Emmerling M, Fiebich BL, Finch CE, Frautschy S, Griffin WS, Hampel H, Hull M, Landreth G, Lue L, Mrak R, Mackenzie IR, McGeer PL, O'Banion MK, Pachter J, Pasinetti G, Plata-Salaman C, Rogers J, Rydel R, Shen Y, Streit W,
Strohmeyer R, Tooyoma I, Van Muiswinkel FL, Veerhuis R, Walker D, Webster S, Wegrzyniak B, Wenk G, Wyss-Coray T (2000) Inflammation and Alzheimer's disease. Neurobiol Aging 21:383-421. doi:10.1016/S0197-4580(00)00124-X

2. Bard F, Cannon C, Barbour R, Burke RL, Games D, Grajeda H, Guido T, Hu K, Huang J, Johnson-Wood K, Khan K, Kholodenko D, Lee M, Lieberburg I, Motter R, Nguyen M, Soriano F, Vasquez N, Weiss K, Welch B, Seubert P, Schenk D, Yednock T (2000) Peripherally administered antibodies against amyloid beta-peptide enter the central nervous system and reduce pathology in a mouse model of Alzheimer disease. Nat Med 6:916-919. doi: $10.1038 / 78682$

3. Carare RO, Bernardes-Silva M, Newman TA, Page AM, Nicoll JA, Perry VH, Weller RO (2008) Solutes, but not cells, drain from the brain parenchyma along basement membranes of capillaries and arteries: significance for cerebral amyloid angiopathy and neuroimmunology. Neuropathol Appl Neurobiol 34:131-144. doi:10.1111/j.1365-2990.2007.00926.x

4. Chen K, Iribarren P, Hu J, Chen J, Gong W, Cho EH, Lockett S, Dunlop NM, Wang JM (2006) Activation of Toll-like receptor 2 on microglia promotes cell uptake of Alzheimer disease-associated amyloid beta peptide. J Biol Chem 281:3651-3659. doi:10.1074/jbc.M508125200

5. Colton CA, Brown CM, Cook D, Needham LK, Xu Q, Czapiga M, Saunders AM, Schmechel DE, Rasheed K, Vitek MP (2002) APOE and the regulation of microglial nitric oxide production: a 
link between genetic risk and oxidative stress. Neurobiol Aging 23:777-785. doi:10.1016/S0197-4580(02)00016-7

6. El Khoury JB, Moore KJ, Means TK, Leung J, Terada K, Toft M, Freeman MW, Luster AD (2003) CD36 mediates the innate host response to beta-amyloid. J Exp Med 197:1657-1666. doi:10.1084/jem.20021546

7. El Khoury J, Toft M, Hickman SE, Means TK, Terada K, Geula C, Luster AD (2007) Ccr2 deficiency impairs microglial accumulation and accelerates progression of Alzheimer-like disease. Nat Med 13:432-438. doi:10.1038/nm1555

8. Fiala M, Looney DJ, Stins M, Way DD, Zhang L, Gan X, Chiappelli F, Schweitzer ES, Shapshak P, Weinand M, Graves MC, Witte M, Kim KS (1997) TNF-alpha opens a paracellular route for HIV1 invasion across the blood-brain barrier. Mol Med 3:553-564

9. Fiala M, Zhang L, Gan X, Sherry B, Taub D, Graves MC, Hama S, Way D, Weinand M, Witte M, Lorton D, Kuo YM, Roher AE (1998) Amyloid-beta induces chemokine secretion and monocyte migration across a human blood-brain barrier model. Mol Med 4:480-489

10. Fiala M, Liu NQ, Reddy S, Graves M (2001) Macrophages infiltrate the brain and express COX-2 and iNOS in Alzheimer's disease and AIDS. Alzheimers Rep 4:1-7

11. Fiala M, Liu QN, Sayre J, Pop V, Brahmandam V, Graves MC, Vinters HV (2002) Cyclooxygenase-2-positive macrophages infiltrate the Alzheimer's disease brain and damage the blood-brain barrier. Eur J Clin Invest 32:360-371. doi:10.1046/j.1365-2362. 2002.00994.x

12. Fiala M, Eshleman AJ, Cashman J, Lin J, Losssinsky AS, Suarez V, Yang W, Zhang J, Popik W, Singer EJ, Chiappelli F, Carro E, Weinand M, Witte M, Arthos J (2005) Cocaine increases human immunodeficiency virus type 1 neuroinvasion through remodeling brain microvascular endothelial cells. J Neurovirol 11:1-11. doi:10.1080/13550280590952835

13. Fiala M, Lin J, Ringman J, Kermani-Arab V, Tsao G, Patel A, Lossinsky AS, Graves MC, Gustavson A, Sayre J, Sofroni E, Suarez T, Chiappelli F, Bernard G (2005) Ineffective phagocytosis of amyloid-beta by macrophages of Alzheimer's disease patients. J Alzheimers Dis 7:221-232 discussion 255-262

14. Fiala M, Cribbs DH, Rosenthal M, Bernard G (2007) Phagocytosis of amyloid-beta and inflammation: two faces of innate immunity in Alzheimer's disease. J Alzheimers Dis 11:457-463

15. Fiala M, Liu PT, Espinosa-Jeffrey A, Rosenthal MJ, Bernard G, Ringman JM, Sayre J, Zhang L, Zaghi J, Dejbakhsh S, Chiang B, Hui J, Mahanian M, Baghaee A, Hong P, Cashman J (2007) Innate immunity and transcription of MGAT-III and Toll-like receptors in Alzheimer's disease patients are improved by bisdemethoxycurcumin. Proc Natl Acad Sci USA 104:12849-12854. doi:10.1073/ pnas.0701267104

16. Frautschy SA, Yang F, Irrizarry M, Hyman B, Saido TC, Hsiao K, Cole GM (1998) Microglial response to amyloid plaques in APPsw transgenic mice. Am J Pathol 152:307-317 see comments

17. Giri R, Shen Y, Stins M, Du Yan S, Schmidt AM, Stern D, Kim KS, Zlokovic B, Kalra VK (2000) Beta-amyloid-induced migration of monocytes across human brain endothelial cells involves RAGE and PECAM-1. Am J Physiol Cell Physiol 279:C1772C1781

18. Gouras GK, Almeida CG, Takahashi RH (2005) Intraneuronal Abeta accumulation and origin of plaques in Alzheimer's disease. Neurobiol Aging 26:1235-1244. doi:10.1016/j.neurobiolaging. 2005.05.022

19. Hamilton JA, Whitty G, White AR, Jobling MF, Thompson A, Barrow CJ, Cappai R, Beyreuther K, Masters CL (2002) Alzheimer's disease amyloid beta and prion protein amyloidogenic peptides promote macrophage survival, DNA synthesis and enhanced proliferative response to CSF-1 (M-CSF). Brain Res 940:49-54. doi:10.1016/S0006-8993(02)02589-1
20. Hardy J, Selkoe DJ (2002) The amyloid hypothesis of Alzheimer's disease: progress and problems on the road to therapeutics. Science 297:353-356. doi:10.1126/science.1072994

21. Husemann J, Loike JD, Anankov R, Febbraio M, Silverstein SC (2002) Scavenger receptors in neurobiology and neuropathology: their role on microglia and other cells of the nervous system. Glia 40:195-205. doi:10.1002/glia.10148

22. Kayed R, Head E, Thompson JL, McIntire TM, Milton SC, Cotman CW, Glabe CG (2003) Common structure of soluble amyloid oligomers implies common mechanism of pathogenesis. Science 300:486-489. doi:10.1126/science.1079469

23. Kayed R, Head E, Sarsoza F, Saing T, Cotman CW, Necula M, Margol L, Wu J, Breydo L, Thompson JL, Rasool S, Gurlo T, Butler P, Glabe CG (2007) Fibril specific, conformation dependent antibodies recognize a generic epitope common to amyloid fibrils and fibrillar oligomers that is absent in prefibrillar oligomers. Mol Neurodegener 2:18. doi:10.1186/1750-1326-2-18

24. Krajewska M, Rosenthal RE, Mikolajczyk J, Stennicke HR, Wiesenthal T, Mai J, Naito M, Salvesen GS, Reed JC, Fiskum G, Krajewski S (2004) Early processing of Bid and caspase-6, -8, -10, -14 in the canine brain during cardiac arrest and resuscitation. Exp Neurol 189:261-279. doi:10.1016/j.expneurol.2004.05.020

25. LaFerla FM, Green KN, Oddo S (2007) Intracellular amyloid-beta in Alzheimer's disease. Nat Rev Neurosci 8:499-509. doi:10.1038/ nrn2168

26. Liu NQ, Lossinsky AS, Popik W, Li X, Gujuluva C, Kriederman B, Roberts J, Pushkarsky T, Bukrinsky M, Witte M, Weinand M, Fiala M (2002) Human immunodeficiency virus type 1 enters brain microvascular endothelia by macropinocytosis dependent on lipid rafts and the mitogen-activated protein kinase signaling pathway. J Virol 76:6689-6700. doi:10.1128/JVI.76.13.6689-6700. 2002

27. Lossinsky AS, Shivers RR (2003) Studies of cerebral endothelium by scanning and high-voltage electron microscopy. In: Nag S (ed) The blood-brain barrier: biology and research protocols, vol 89 . Humana Press, Totawa, pp 67-82

28. Majumdar A, Chung H, Dolios G, Wang R, Asamoah N, Lobel P, Maxfield FR (2008) Degradation of fibrillar forms of Alzheimer's amyloid beta-peptide by macrophages. Neurobiol Aging 29:707715. doi:10.1016/j.neurobiolaging.2006.12.001

29. McKhann G, Drachman D, Folstein M, Katzman R, Price D, Stadlan EM (1984) Clinical diagnosis of Alzheimer's disease: report of the NINCDS-ADRDA Work Group under the auspices of Department of Health and Human Services Task Force on Alzheimer's Disease. Neurology 34:939-944

30. Mildner A, Schmidt H, Nitsche M, Merkler D, Hanisch UK, Mack M, Heikenwalder M, Bruck W, Priller J, Prinz M (2007) Microglia in the adult brain arise from Ly-6C(hi)CCR2(+) monocytes only under defined host conditions. Nat Neurosci 10:1544-1553. doi:10.1038/nn2015

31. Mrak RE, Griffin WS (2005) Potential inflammatory biomarkers in Alzheimer's disease. J Alzheimers Dis 8:369-375

32. Nixon RA (2007) Autophagy, amyloidogenesis and Alzheimer disease. J Cell Sci 120:4081-4091. doi:10.1242/jcs.019265

33. Oddo S, Caccamo A, Tran L, Lambert MP, Glabe CG, Klein WL, LaFerla FM (2006) Temporal profile of amyloid-beta (Abeta) oligomerization in an in vivo model of Alzheimer disease. A link between Abeta and tau pathology. J Biol Chem 281:1599-1604. doi:10.1074/jbc.M507892200

34. Paresce DM, Ghosh RN, Maxfield FR (1996) Microglial cells internalize aggregates of the Alzheimer's disease amyloid betaprotein via a scavenger receptor. Neuron 17:553-565. doi:10.1016/ S0896-6273(00)80187-7

35. Sagare A, Deane R, Bell RD, Johnson B, Hamm K, Pendu R, Marky A, Lenting PJ, Wu Z, Zarcone T, Goate A, Mayo K, Perlmutter D, Coma M, Zhong Z, Zlokovic BV (2007) Clearance of 
amyloid-beta by circulating lipoprotein receptors. Nat Med 13:1029-1031. doi:10.1038/nm1635

36. Simard AR, Rivest S (2006) Neuroprotective properties of the innate immune system and bone marrow stem cells in Alzheimer's disease. Mol Psychiatry 11:327-335. doi:10.1038/sj.mp.4001809

37. Simard AR, Soulet D, Gowing G, Julien JP, Rivest S (2006) Bone marrow-derived microglia play a critical role in restricting senile plaque formation in Alzheimer's disease. Neuron 49:489-502. doi:10.1016/j.neuron.2006.01.022

38. Smits HA, Rijsmus A, van Loon JH, Wat JW, Verhoef J, Boven LA, Nottet HS (2002) Amyloid-beta-induced chemokine production in primary human macrophages and astrocytes. J Neuroimmunol 127:160-168. doi:10.1016/S0165-5728(02)00112-1

39. Solomon B (2007) Intravenous immunoglobulin and Alzheimer's disease immunotherapy. Curr Opin Mol Ther 9:79-85

40. Stoll G, Jander S (1999) The role of microglia and macrophages in the pathophysiology of the CNS. Prog Neurobiol 58:233-247. doi:10.1016/S0301-0082(98)00083-5

41. Stuart LM, Bell SA, Stewart CR, Silver JM, Richard J, Goss JL, Tseng AA, Zhang A, El Khoury JB, Moore KJ (2007) CD36 signals to the actin cytoskeleton and regulates microglial migration via a p130Cas complex. J Biol Chem 282:27392-27401. doi:10.1074/ jbc.M702887200

42. Tanzi RE, Moir RD, Wagner SL (2004) Clearance of Alzheimer's Abeta peptide: the many roads to perdition. Neuron 43:605-608

43. Tseng BP, Green KN, Chan JL, Blurton-Jones M, LaFerla FM (2008) Abeta inhibits the proteasome and enhances amyloid and tau accumulation. Neurobiol Aging 29:1607-1618. doi:10.1016/ j.neurobiolaging.2007.04.014

44. Van Dorpe J, Smeijers L, Dewachter I, Nuyens D, Spittaels K, Van Den Haute C, Mercken M, Moechars D, Laenen I, Kuiperi C, Bruynseels K, Tesseur I, Loos R, Vanderstichele H, Checler F, Sciot R, Van Leuven F (2000) Prominent cerebral amyloid angiopathy in transgenic mice overexpressing the London mutant of human APP in neurons. Am J Pathol 157:1283-1298

45. Webster SD, Yang AJ, Margol L, Garzon-Rodriguez W, Glabe CG, Tenner AJ (2000) Complement component C1q modulates the phagocytosis of Abeta by microglia. Exp Neurol 161:127-138. doi:10.1006/exnr.1999.7260
46. Webster SD, Galvan MD, Ferran E, Garzon-Rodriguez W, Glabe CG, Tenner AJ (2001) Antibody-mediated phagocytosis of the amyloid beta-peptide in microglia is differentially modulated by C1q. J Immunol 166:7496-7503

47. Wegiel J, Kuchna I, Nowicki K, Frackowiak J, Mazur-Kolecka B, Imaki H, Mehta PD, Silverman WP, Reisberg B, Deleon M, Wisniewski T, Pirttilla T, Frey H, Lehtimaki T, Kivimaki T, Visser FE, Kamphorst W, Potempska A, Bolton D, Currie JR, Miller DL (2007) Intraneuronal Abeta immunoreactivity is not a predictor of brain amyloidosis-beta or neurofibrillary degeneration. Acta Neuropathol 113:389-402. doi:10.1007/s00401-006-0191-4

48. Weiner HL, Frenkel D (2006) Immunology and immunotherapy of Alzheimer's disease. Nat Rev Immunol 6:404-416. doi:10.1038/ nri1843

49. Weller RO, Nicoll JA (2003) Cerebral amyloid angiopathy: pathogenesis and effects on the ageing and Alzheimer brain. Neurol Res 25:611-616. doi:10.1179/016164103101202057

50. Wilcock DM, DiCarlo G, Henderson D, Jackson J, Clarke K, Ugen KE, Gordon MN, Morgan D (2003) Intracranially administered anti-Abeta antibodies reduce beta-amyloid deposition by mechanisms both independent of and associated with microglial activation. J Neurosci 23:3745-3751

51. Wisniewski HM, Wegiel J (1994) Beta-amyloid formation by myocytes of leptomeningeal vessels. Acta Neuropathol 87:233241. doi:10.1007/BF00296738

52. Wisniewski HM, Wegiel J, Wang KC, Lach B (1992) Ultrastructural studies of the cells forming amyloid in the cortical vessel wall in Alzheimer's disease. Acta Neuropathol 84:117-127. doi:10.1007/BF00311383

53. Yamada M, Itoh Y, Shintaku M, Kawamura J, Jensson O, Thorsteinsson L, Suematsu N, Matsushita M, Otomo E (1996) Immune reactions associated with cerebral amyloid angiopathy. Stroke 27:1155-1162

54. Zhang L, Fiala M, Cashman J, Sayre J, Espinosa-Jeffrey A, Mahanian M, Zaghi J, Badmaev V, Graves M, Bernard G, Rosenthal M (2006) Curcuminoids enhance amyloid-beta uptake by macrophages of Alzheimer's disease patients. J Alzheimers Dis $10: 1-7$ 